\title{
Plant Impressions and Sporomorphs from Kurnub Sandstone Formation in North Jordan
}

\author{
Mona H. Darwish \\ Botany Department, Faculty of Girls , \\ Ain Shams University. Cairo- Egypt.
}

Darwish, M.H.1999. Plant Impressions And Sporomorphs From Kurnub Sandstone Formation In North Jordan Taeckholmia 19(1):1-16.

Impressions of fragments of vegetative organs of a few ferns are recorded from Lower Cretaceous sandstone beds in Kurnub Formation, in Al Baqaa area, North Jordan. Spore-pollen assemblages, also indicating Early Cretaceous age, were found in samples containing plant macro-remnants.

Key Words: Fern Prints, Jordan, Kurnub Sandstone Formation, Sporomorphs

\section{Introduction}

The Lower Cretaceous sediments in Jordan consist mostly of sandstone with intercalations of claystones of deltaic and fluviatile origin, in addition to marine carbonate interbeds (Fayez and Hakam, 1994). Abed $(1978,1982)$ described the sandstones in North Jordan in general as varicolored, friable, quartz-arenitic sandstone attains a thickness of $300 \mathrm{~m}$. He postulated that these sandstones are of fluvial origin with a few interfingering shallow marine horizons.

Abed (1982) reported rich fern-like macroflora from the siltstone facies at Kurnub locality in North Jordan.

The present study is an attempt to clarify the stratigraphical position and partially depositional conditions of Kurnub Sandstone (Fig. 1) by studying its macro and microfloral content.

\section{Materials and methods}

Materials forming the basis of this study are three slabs containing plant impressions (Plate 1). The flora consists of fragmentary remains of ferns and some other unidentifiable plant remains. All are preserved as impressions without any organic matter remains.

A brief description of the different strata of the Kurnub Formation is given in Fig. 2. 
M.H. Darwish

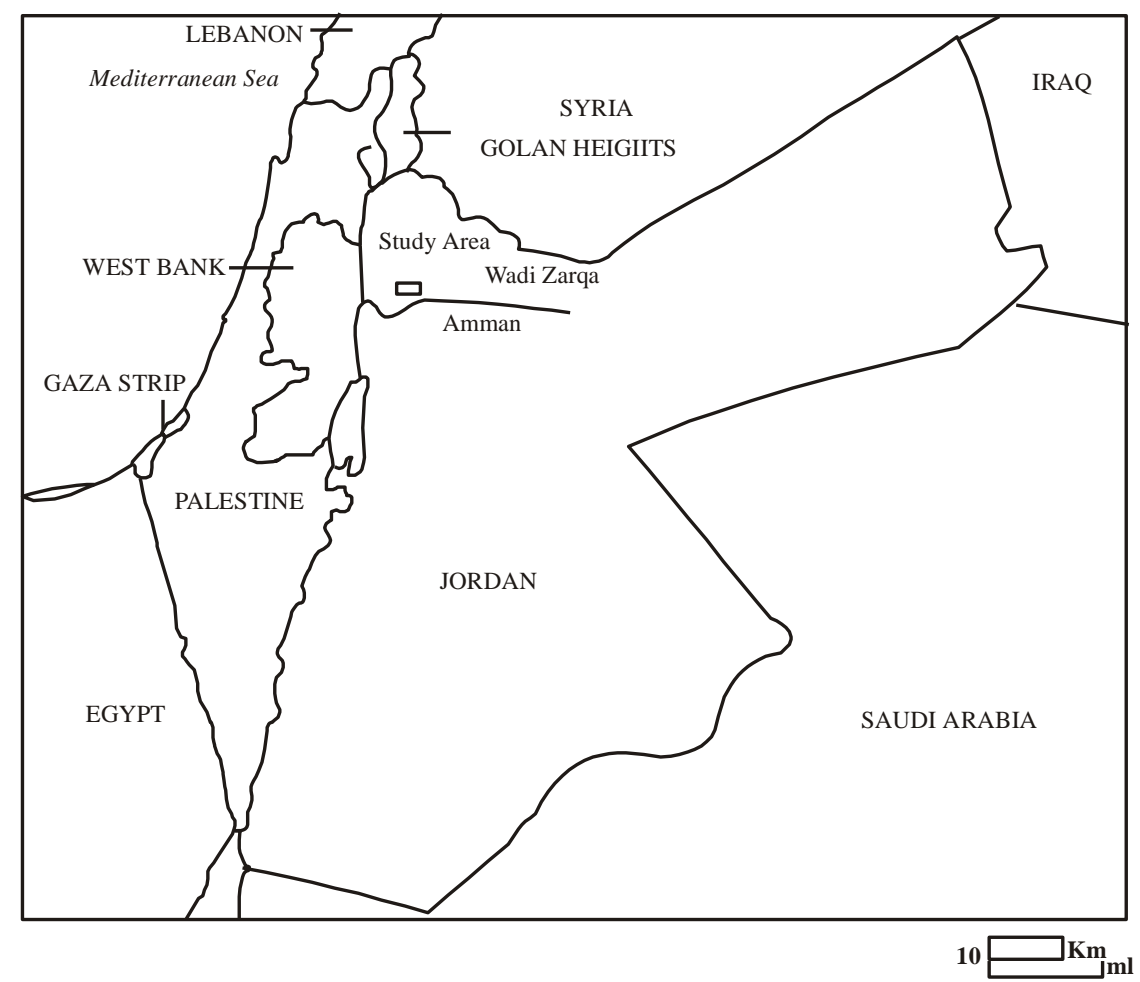

Fig. 1. Location Map of the study Area

For investigation of the palynomorphs, the samples were treated first with $\mathrm{HCl}$. After washing with water, HF was added to the organic matter-containing residue to eliminate the silicate and other inorganic components. Finally, the slides, for lightmicroscope investigations were prepared in glycerin-jelly. 


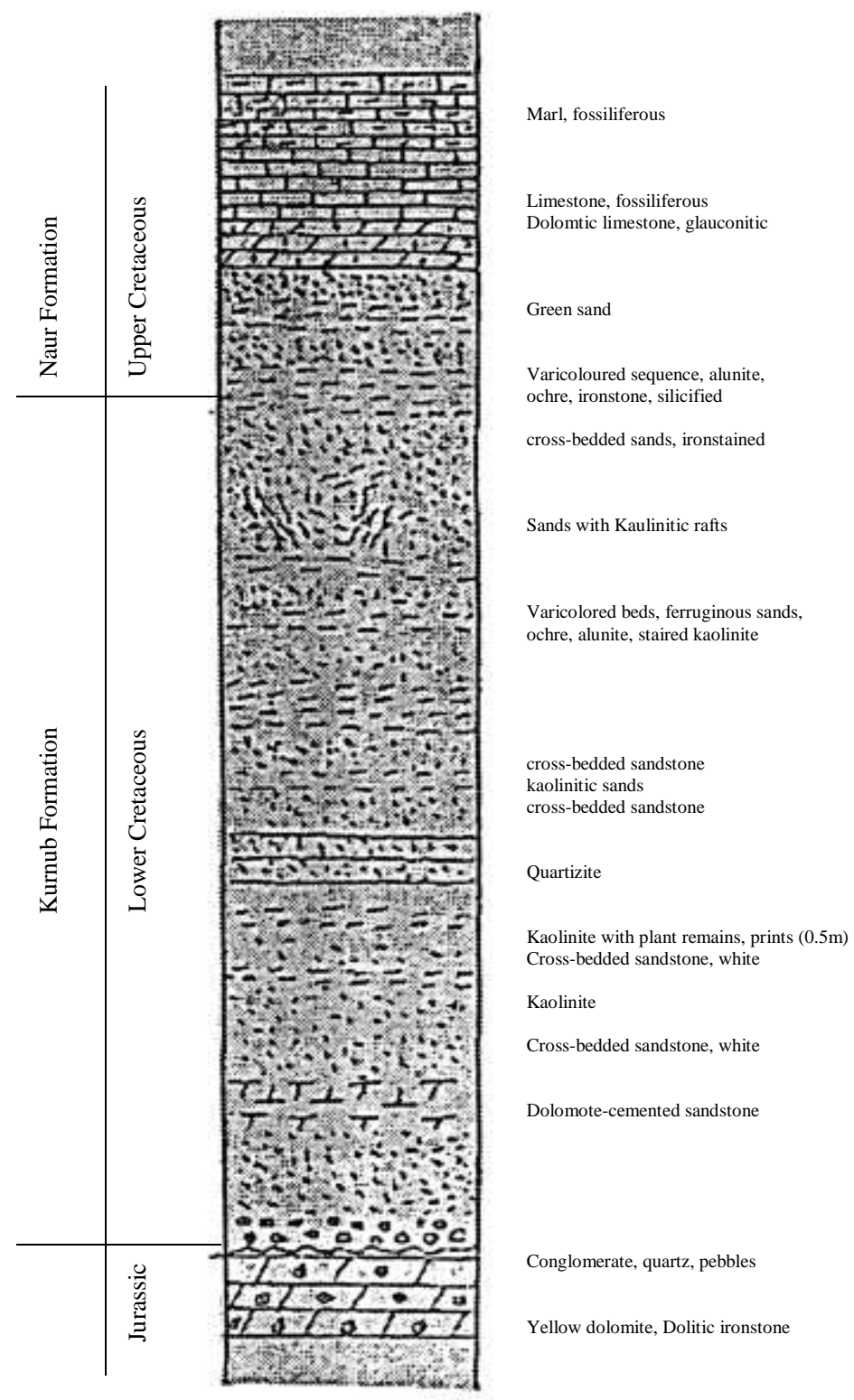

Fig. 2. Stratigraphy of the Kurnub Formation in $\mathrm{Al}$ Baqaa area, Jordan. (Courtesy Prof. Dr. M. El-Sharkawi ). 
M.H. Darwish

\section{Results}

\section{Plant macrofossils}

The fossil flora of Kurnub sandstone represented in the three slabs, consists of three taxa. Each slab contains only one taxon. Description is based on the best-preserved fossil fragments of the taxa.

\section{Description of the Macrofossils}

Division: Pteridophyta

Class: Pteropsida

Order : Filicales

Family: $\quad$ Aspleniaceae Gray 1821.

Genus: Asplenium Linnaeus 1753. Asplenium whitbyense Heer.

Plate 1, Fig. 1.

Description: The frond is bipinnate but incomplete .The best-preserved specimen is about $60 \mathrm{~mm}$ long and $40 \mathrm{~mm}$ broad. Rachis of frond is about $6 \mathrm{~mm}$ wide. Pinnae are also incomplete, the longest pinna was found to carry 12 pairs of pinnules. The angle of insertion of pinnae on the frond rachis is from 65 to 85 degrees. Pinna rachis is about 0.5 $\mathrm{mm}$ wide. Pinnules are opposite. The angle of insertion of pinnules on the pinna rachis is from 80 to 90 degrees. They are crowded on the pinna rachis with thin gaps between adjacent pinnules. Pinnules are quadrangular to rectangular in shape, about 2-mm long and about $1 \mathrm{~mm}$ wide, with entire margins and rounded apices . Pinnule midrib is stout at base, terminating at lamina apex. Lateral veins are not clear. Sterile fragments only are present. The frond has a feather shape.

Order: $\quad$ Filicales

Family: Dicksoniaceae Bower 1908

Genus: $\quad$ Coniopteris Brongniart 1849.

Coniopteris arguta Lindley and Hutton

Plate 1, Fig. 2.

Description: The frond is bipinnate but incomplete. The best specimen is $154 \mathrm{~mm}$ long, one frond was found to carry 17 pairs of pinnae. Rachis of frond is about $12 \mathrm{~mm}$ wide. The angle of insertion of pinnae on the frond rachis is 80 to 90 degrees. Pinnae are opposite. They are crowded on the frond rachis with gaps, about 0.5 to $2 \mathrm{~mm}$ wide, inbetween.

The largest pinna is about $90-\mathrm{mm}$ long and $10 \mathrm{~mm}$ broad and carries 30 pairs of pinnules. Pinna rachis is distinct, about $1 \mathrm{~mm}$ wide. The pinnules are nearly perpendicular to the pinna rachis. They are opposite or almost so. They are crowded on the pinna rachis with gaps about 0.2 to $0.4-\mathrm{mm}$ wide in-between. There is no connecting web. Pinnules are 5 to $7 \mathrm{~mm}$ long and 2 to $5 \mathrm{~mm}$ wide (largest pinnules are at the middle of pinna), with entire margins and obtuse apices. Pinnule midrib is very thin. Venation is not visible. Sterile fragments only are present. 


\section{Genus: $\quad$ Callipteridium Weis 1870 \\ Callipteridium pteridium Schloth. \\ Plate 1, Fig. 3 .}

Description: This is a species of fern -like foliage. Entire frond is unknown. The specimen is $11 \mathrm{~mm}$ long and 6 to $7 \mathrm{~mm}$ wide. Pinna is incomplete; it carries 30 pairs of pinnules. Pinna rachis is about $1 \mathrm{~mm}$ wide. The angle of insertion of pinnules on pinna rachis is from 50 to 60 degrees. Pinnules are opposite. They are crowded on the pinna rachis with thin gaps about $1.2 \mathrm{~mm}$ wide in-between. Connecting web is distinct. Pinnules are well preserved, triangular being 3 to $4 \mathrm{~mm}$ long and about 0.5 to $0.7 \mathrm{~mm}$ wide, with entire margins, and blunt rounded apices. Pinnule midrib is thin but distinct. This specimen has sterile pinnules only.

\section{Comparisons}

Morphological convergence is evident between the foliage of the present specimen of Asplenium whitbyense and foliage of Anemia fremontii Knowlton recorded by Crabtree (1988) from Albian of Southwestern Montana (U.S.A), but A. fremontii has linear pinnules with acute apices. The present specimen is identical with A.whitbyense which was described from Upper Jurassic- Lower Cretaceous beds of Abu- Darag,Egypt ( Darwish ,1990). A. whitbyense resembles also Cladophlebis sp. reported from Upper Jurassic -Lower Cretaceous beds of Abu- Darag, Western side of Gulf of Suez ( Darwish, 1990) but here the pinnules are smaller and have almost quadrangular shape, not oblong.

Coniopteris arguta is similar to Phlebopteris but is separated on basis of its bipinnate leaves ( Phlebopteris being once pinnate Person \& Delevoryas, 1982). The present specimen is closely similar to a specimen of $C$. arguta described by Person \& Delevoryas (1982) from the Jurassic of Mexico but here the pinnae are perpendicular to the frond rachis. C. vinyardii described by Crabtree (1988) from the Albian of Southwestern Montana (U.S.A.) differs from the present C. arguta in having tripinnte leaves and pinnae are not perpendicular to the frond rachis. C. arguta reported here is very similar to specimens of the same species described form Upper Jurassic- Lower Cretaceous of Abu-Darag ,Egypt by (Darwish ,1990) but here pinnules are larger.

Callipteridium pteridium differs from Odontopteris cantbrica, described by Boersma (1978) from Early Stephanian of Germany in having alternate pinnules, and the connection between pinnules is very thin. C. pteridium reported here is identical with that recorded from Abu-Darag locality (Darwish ,1990).

This means that the species A. whitbyense, C. arguta, and C. pteridium are common to both Kurnub and Abu- Darag localities . Further detailed studies of both localities may prove that there are more species in common, not only concerning ferns but also Cycadophytes and Coniferales (cf. Edwards, 1929 ; El-Saadawi and Farag,1972 ; El-Saadawi and Kedves 1991) .

The Kurnub flora is also similar to Mesozoic floras in other strata of the world. For example in North America, ferns are so prevalent and abundant in Late Jurassic and Early Cretaceous megafloras (Niklas, et al. 1980; Crabrtee, 1988; Rushforth 1976). ElSaadawi and Farag (1972) and Darwish (1990) gave also similar statements concerning the abundance of ferns in Early Cretaceous of Abu-Darag. 


\section{Plant Microfossils}

The following is the taxonomic list of the fossil miospore species identified in the present study. The system of classification adopted here is a semi-natural one; based on Inversen and Troels-Smith (1950) for the pollen grains, Potonie (1956) for the spores and Erdtman (1948) for the morphological terminology with slight modification. The trilete spores are classified according to the nature of exine sculpture. All psilate spores are grouped together under Psilatriletes.

Genus: Cyathidites Couper 1953.

1.Division Sporites

A. Subdivision Triletes

Group Psilatriletes

Cyathidites australis Couper 1953 (Plate 2, Figs.1\& 2)

Cyathidites minor Couper 1958 (Plate 2, Fig.3)

Cyathidites sp. (Plate 2, Fig. 4).

Genus: Dictyophyllidites Couper 1958, emend, Dettmann 1963.

Dictyophyllidites cf. harrisiiCouper 1958 (Plate 2, Fig.5)

Genus: Concavisporites Pflug 1953.

Concavisporites twentianus Burger 1966 (Plate 2, Fig, 6)

Group Verrutriletes

Genus: Concavissimisporites (Del. \& Sprum. 1955)

Concavissimisporites sp. (Plate 2, Fig. 7)

Genus: Verrucosisporites (Ibrahim 1933) Pot. \& Kremp 1954

Verrucosisporites cf. rarus Burger 1966 (Plate 2, Fig. 8)

Verrucosisporites sp. (Plate 2, Fig. 9)

Group Striatriletes

Genus: Cicatricosisporites Potonie and Gelletich 1933.

Cicatricosisporites cf. type H. Saad 1978 (Plate 2, Fig. 10)

Cicatricosisporites sp. 1 (Plate 2, Fig. 11)

Cicatricosisporites sp. 2 (Plate 2, Fig. 12)

Group Perinotriletes

Genus: $\quad$ Perotriletes Erdtman 1948 ex Couper 1953

Perotriletes pannuceus Brenner 1963 (Plate 2, Fig. 13)

Perotriletes perinopustulosus Reyre1973(Plate 2, Fig.14)

Perotriletes sp. 1 Reyre 1973 (Plate 2, Fig. 15)

Perotriletes sp. ( Plate 2, Fig. 16 )

B . Subdivision Monoletes

Group Azonomonoletes

Genus : $\quad$ Laevigatosporites Ibrahim 1933

Laevigatosporites sp. ( Plate 3, Fig. 4 )

Division Pollenites

A. Subdivision Gymnospermae

Group Tetradae

Genus: $\quad$ Classopollis (Pflug 1953) Pocock and Jansonicus 1961.

Classopollis tumulus? (Plate 4, Fig. 20)

Classopollis sp. (Plate 4, Fig. 21)

Group Vesiculatae 
Genus Callialasporites Sukh Dev 1961

Callialasporites dampieri (Balme 1957) Dev 1961 (Plate 3, Figs. 1, 2)

Callialasporites segmentatus (Balme 1957) Dev 1961 (Plate 3, Fig. 3)

Genus Araucariacites Cookson 1947 ex Couper 1953

Araucariacites australis Cookson 1947 (Plate3,Figs.5,6)

Group Inaperturatae

Genus: Inaperturopollenites Thomson and Pflug 1953.

Inaperturopollenites sp. 1 (Plate 3, Fig. 7)

Inaperturopollenites sp. 2 (Plate 3, Fig. 8)

Group Polyplicatae

Genus: $\quad$ Ephedripites Bolkhovitina 1953 ex Potonie 1958.

Ephedripites type E. Saad 1978 (Plate 3, Fig. 9)

Ephedripites multicostatus Brenner 1963 (Plate 3, Fig.10)

Ephedripites cf. Validus Brenner 1968 (Plate 3, Fig. 11)

Ephedripites sp. 1 (Plate 3, Fig. 13)

Ephedripites sp. 2 (Plate 3, Fig. 14)

Ephedripites sp. 3 (Plate 3, Fig. 15)

Equisetosporites cf. ambigus singh1983 (Plate 3, Fig. 12)

Group Monosulcatae

Genus: Cycadopites Wilson and Webster 1946.

Cycadopites glottus (Brenner)Wingate 1980 (Plate 4,Figs. 10, 11) Cycadopites sp. (Plate 4, Figs. 12\&13)

Group Praecolpatae

Genus: Eucommiidites (Erdtmann 1948) Hughes 1961.

Eucommiidites troedssonii Erdmann 1948 (Plate 4, Fig. 1)

Eucommiidites spp. (Plate 4, Figs. 14-17)

Subdivision Angiospermae

Group Monocolpatae

Genus: $\quad$ Monocolpopollenites Thomson and Pflug 1953.

Monocolpopollenites type A, Saad \& Ghazaly 1976 (Plate 4, Fig. 4)

Monocolpopollenites sp (Plate 4, Figs. 5-8)

Group Tricolpatae

Genus: $\quad$ Tricolpites Cookson 1947 ex Couper 1958.

Tricolpites cf. virgus (Groat et. al.) 1961 (Plate 4, Fig. 18)

Tricolpites sp. (Plate 4, Figs. 2,3 \&19)

Genus : $\quad$ Liliacidites Couper 1953.

Liliacidites sp. (Plate 4, Fig. 9)

\section{Plant tissue remnants}

Epidermis fragments of Monocotyledonopsida type (Plate 5, Figs.3, 5 \&6)

Gymnosperm secondary xylem fragments of tracheids with bordered pits (Plate 5, Fig. 4). Unidentified plant tissues (may be tissues of ferns?) (Plate 5, Figs. 1\&2).

\section{General Discussion And Conclusions}

The palynomorph assemblages of Kurnub Sandstone are not diverse and possess numerous elements which have been described from Early Cretaceous and could also be 
continued downwards to Late Jurassic. As far as known, the definition of Late Jurassic Early Cretaceous contact is always a matter of controversy, as the microfloras of the two ages are too closely similar and biostratigraphic value of many taxa is still uncertain. However, the age assignment of the described assemblage could be achieved by comparison with stratigraphically well defined assemblages in other regions.

The assemblage as a whole comprises 18 genera and 48 species.

It is characterized by the dominance of trilete spores, which contribute 7 genera and 15 species. The monoletes is represented by 1 genus and 1 species. The gymnosperms pollen comprise 7 genera and 16 species. The angiosperms pollen are represented by 3 genera and 6 species.

The distribution of the spores and pollen grains in Kurnub sandstone Formation indicates that the climate changed from humid to arid-semiarid (Pteridophytic spores form $44 \%$, gymnosperm pollen grains $39 \%$ and angiosperm pollen $17 \%$ ). The appearance of angiosperms indicates that abrupt changes in environmental conditions have taken place.

The presence of some sporomorphs such as Inaperturopollenites and Cyathidites have been reported by Saad and Ghazaly (1976) from Kharga Oasis in Egypt and by Fayez and Hakam (1994) from Kurnub sandstone in Wadi Zarqa , in North Jordan . They gave them late Jurassic-Early Cretaceous age but existence of angiosperm excludes the Late Jurassic. Generally recognized angiosperm forms appear in the fossil record in Early Cretaceous times (Cran et. al., 1986).

Herngreen and Chlonova (1981) gave the gymnosperm pollen grains, Araucariacites, Inaperturopollenites, Classopollis and Eucommiidites, Late Jurassic to Neocomian age, and they gave the monosulcites gymnosperm pollen a Neocomian age.

Ibrahim, et. al. (1995) stated that Barremian age is characterized by the first incoming of Ephedripites pollen and primitive angiosperm pollen like Liliacidites and others. Ephedripites and others dominate the Albian microflora .The percentage of angiosperm pollen increased during the Aptian, tricolpate pollen, Afropollis and others appeared.. Tricolporate angiosperm and elater bearing elements are present in the EarlyMiddle Cenomanian.

Aboul Ela, et. al. (1989) reported that Cicatricosisporites is important through the Barriasian-Hauterivian rocks of NW Europe and have been shown by Huges and Croxton (1973) and many other workers to have considerable value for stratigraphic correlation. On the other hand, Herngreen and Chlonova (1981) stated that the presence of Cicatricosisporites indicates an age that is not older than Late Jurassic. This is supported by the opinion of Lantz (1958) and Jakhovskty (1959) that this genus appeared in Kimmeridgian-Purbeckian age. Perotrilites appeared in the Neocemian-Barremian (Abdekmalek et. al. 1981). Perotriletes pannuceus is known to appear first in Late Cenomanian and continued down into Albian where it disappeared (Herngreen 1975).

Cycadopites, Eucommiidites troedssonii, Ephedripites type E-Saad (1978) are described by Schrank (1987) from Late Jurassic-Early Cretaceous of the North Western Desert of Egypt from Barremian of Umbarka well.Eucommiidites, Ephedripites and Araucariacities characterize the pre-Albian of West Africa-South America province (WASA) as suggested by Herngreen and Chlonova (1981) and as Aboul Ela, et. al. (1989) stated that this microflora is found at Abu Darag in Egypt . Huges and Mcdougall (1987) mentioned that the first appearance of Ephedripities is in Barremian- Albian age.

El-Saadawi and Kedves (1991) found Classopollis, Eucommiidites, Ephedripites, fragments of Monocotyledonopsida and Gymnosperm secondary xylem fragments of tracheids with bordered pits at Abu Darag in Egypt, they gave it an Early Cretaceous age. 
The first appearance of the Tricolpites indicates strongly the beginning of the Albian, as Couper and Huges (1963) define the first apperance of Tricolpites pollen to be in the Late Aptian to Early Albian. Fayez and Hakam (1994) found Tricolpites in the same age from Kurnub Sandstone. Saad (1975) gave Cretaceous at Kharaga Oasis a SontonianCampanian age based on the presence of Monocolpopollenites and Tricolpites. Magdy (1998) said that the presence of relatively large angiosperm pollen ( e.g. Tricolpites spp.) indicates a Campanian age for the Quseir Formation ,Kharga Oasis, (Egypt).

The recovered microflora, therefore, indicates an Early Cretaceous age and can be extended to Late Jurassic. However, the Early Cretaceous is widely viewed as the starting point of angiosperm evolution (Beck 1976, Cronquist 1988).

The predominance of fern foliage and fine delicate parts of plant remains in the studied sediment can be attributed to prolonged period of transportation, where the large heavy woody fragments have been left and these delicate plant tissues have been transported away to the site of deposition. The apparent lack of diversification in the pollen and spores in the studied samples may be related to poor preservation under increasingly subaerial continental condition.

\section{Acknowledgement}

I wish to thank Dr. M. El-Sharkawi (Prof. of Geology, Fac. Sc. Cairo Univ.) for kindly supplying me with the studied specimens and the Stratigraphy of the Kurnub Formation in Al Baqaa area Sincere thanks are also to Dr. W. El-Saadawi (Prof. Botany, Ain Shams Univ., Cairo) and Dr. N. Aboul Ela (Prof. of Geology, Fac. Sc. Cairo Univ.) for their kind help, and encouragement .

\section{References}

Abdelmalek, W.M., Aboul Ela, N.M. \& El-Shamaa A.G. 1981. Upper Jurassic-Lower Cretaceous microflora from the North Western Desert, Egypt. N. Jb. Geol. palaont. Abhb., 162 ( 2): 244-263.

Abed, A.M. 1978. Depositional environments of the Kurnub (Lower Cretaceous) sandstone: 1.A. coal horizon at the lowermost Kurnub, North Jordan, Dirasat:9.

Abed, A.M. 1982. Depositional environments of the Early Cretaceous Kurnub (Hathira) sandstones, North Jordan, Sedimentary Geology 31:267-279.

Aboul Ela, N.M., El-Saadawi, W.E. \& Darwish, M.H. 1989. Some Lower Cretaceous microfloras from Abu- Darag area, Western side of the Gulf of Suez. Egypt. Egypt.J. Geol, 33 : 347-361.

Balme, B.E. 1957. Spores and Pollen grains from the Mesozoic of Western Australia. Comm. Sci Indust. Res. Org.. Coal Res. Sect. Chatswood : 1-50 .

Beck, C.B. 1976. Origin and early evolution of angiosperms: a perspective. : 1-10 in C.B. Beck, ed. Origin and early evolution of angiosperms. Columbia University Press. New York.

Boersma, M. 1978. A survey of the Fossil Flora of the "Illinger Flozzone" ("Heusweiler schichten', Lower Stephanian, SAAR, GERMAN FEDERAL REPUBLIC ). Rev. of Palaeobotany \& Palynology 26: 41-92.

Bolkhovitina, N.A. 1953. Spore-pollen assemblages of the Cretaceous of the central part of the U.S.S.R. Trudy Akad. Nauk S.S.S.R., Geol Ser.: 61. 
Brenner, G.J. 1963. The spores and pollen of the Potomac Group of Maryland. Maryland Board Nat. Res. Dept. Geol., Mines Water Resources Bull. 27 :1-215.

Brenner, G.J. 1968. Middle Cretaceous spores and Pollen from northeastern Preu. Pollen et Spores 10 (2) :341-383 .

Burger, D. 1966. Palnology of Uppermost Jurassic and Lowermost Cretaceous strata in the eastern Netherlands. J.J. Groen \& Zoon, Leiden.

Cookson,1.C.1947. Plant microfossils from the lignites Kerguelen Archipelago. B. A. N. Z.Antract. Res.Exp.1929- 1931.Reports ser. A (2).

Couper, R.A. 1953. Upper Mesozoic and Cainozoic spores and pollen grains from New Zealand. N.Z. Geol. Surv. Paleont. Bull.22 : 1-77.

Couper, R. A. 1958. British Mesozoic microspores and pollen grains, A systematic and stratigraphic study. Palaeontographica $B$, 103: 75-179.

Couper, R.A. \& Huges, N.F. 1963. Jurassic and Lower Cretaceous palynology of the Netherlands and adjacent area. Vern. k. Geol. Mijinb. Genoot. Geol.Ser. 21 (2) :105-108.

Crabtree, D.R. 1988. Mid Cretaceous ferns in situ from the Albino member of the Mowry shale, Southwestern Montana Palaeontographica Abt. B, 209, Lfg.1-3 : 1-27.

Crane, PR, Fries, E.M., \& Pedersen, K.R. 1986. Lower Cretaceous angiosperm flowers: fossil evidence on early radiation of Dicotyledons. Science 232 : 852-854.

Cronquist, A. 1988 . The Evolution and Classification of Flowering Plants. New York Botanical Garden. New York.

Darwish, M.H. 1990. Studies on some Egyptian fossil plants. Ph.D. Thesis. Ain Shams Univ. Cairo.

Delcourt, A.F. \& Sprumont, G. 1955. Les spores et grains de pollen du Wealdien du Hainaut. Mem. Soc. geol. Bruxelles, N.S.:73.

Edwadrs, W. N. 1929 . Lower Cretaceous plant from Syria and, Transjordania . Ann. And Mag. Nat. Hist. Ser. 10, 4 : 394-405.

El-Saadawi, W.E. \& Farag, E. 1972 . Some Mesozoic plants from Abu-Darag, western side of Gulf of Suez. J.Bot. U. A. R. 15: 121-130.

El-Saadawi, W.E.\& Kedves,M.1991.Palaeobotanical investigations on plant impressions and sporomorphs from Egypt .Plant Cell Biology and Development (2) : 8-33.

Erdtman, G. 1948. Did dicotyledonous plants exist in Early Jurassic times? Geol. Foren. Stockh. Forh. 70: 265-271.

Fayez, A. \& Hakam, 1994. Pollen and spores from the Kurnub Sandstone Formation (Early Cretaceous ), in North Jordan. Abhath Al-Yarmouk. Pure. Sc. \& Eng. 3 (1): 125-192.

Herngreen , G. F. W. 1975. Palynology of Middle and Upper Cretaceous strata in Brazil . Meded. R.G.D., N. S. 26 (3) : 39-91.

Herngreen, G. F. W. \& Chlonova, A.E. 1981. Cretaceous microfloral provinces. Pollen et Spores 23 :441-555.

Hughes, N.F. 1961. Further interpretation of Eucommiidites Erdtman (1948). Palaeontology: 4 (2).

Hughes, N.F. \& Croxton, C.A. 1973, Palynologic correlation of the Dorset (Wealden). Palaeont. 16 (3) : 567-601.

Hughes, N. F. \& Mc Dougall, A.B. 1987. Records of angiospermid pollen entry into the English Early Cretaceous succession. Review of Palaeobotany and Palynology 50 :255-272.

Ibrahim, A.1933. Sporen Formen des Aegirhorizontes des Ruhrreviers. Diss. TH., Berlin. 
Ibrahim, M.I., Schrank, E. \& Abdel-Kireem, M.R. 1995. Cretaceous Biostraigraphy and Palaeogeography of North Egypt and Northeast Libya. PRJ .14 (3) :75-93.

Inverness, J. \& J. Troels-Smith,1950 . Pollenmorfologisk definitioner og typer. dan. Geol. Unders . IV Raekke 3 (8): 54. Aiso as: Pollen morphological definitions and types. Dan. Geol. Unders. Arbog 1980: 5-27.

Jekhowsky, B. 1959. Une technique standard de preparation des roches pour l'etude des microfossiles organiques. Rev. I.F.P.16 (3) : 315-320.

Lantz, J. 1958. Etude palynologue de quelques echantillons mesozoiques du Dorset (Grande Bretagne ). Rev. Inst. Fr. Petrol. 13 (6) : 917-943.

Magdy, S. M. 1998. Palynological Dating of the Quseir Formation, Kharga Oasis (Egypt). Arab Gulf J. Scient. Res. 16 (2) : 267-281 .

Niklas, K.J., Tiffney, B.H. \& Knoll, A.H. 1980. Apparent changes in the diversity of fossil plants. p. 1-89, in Hecht, M.K., Steere, W.C. \& Wallace, B. (eds), Evolutionary Biology 12. Plenum Publishing Crop.

Person, C.P. \& Delevoryas, T. 1982. The Middle Jurassic flora of Oaxaca Mexico. Palaeontographica Abt. B. 180, Lfg. 4-6: 82-119.

Pflug, H.D. 1953. Zur Entstehung und Entwicklung de angiospermiden pollens in der Erdgeschichte. Palaeontographica B, 95: 60-171.

Pocock, S.A. \& Jansonius, J. 1961, The pollen genus Classopollis Pflug 1953. Micropaleontology 7: 439-449.

Potonie, R. \& Gelletich, J. 1933, Uber Pteridophyten-Sporen einer Eozanen Braunkohle aus Dorog in Ungarn. Sitz.-Ber. Naturforsch. Ges. Freunde (1932) 33 :517-528.

Potonie, R. \& Kremp, G.O.W. 1954, Die Gattungen der palaeozoischen Sporae dispersae und ihre Stratigraphie. Geol. Jb.69: 111-194.

Reyer, Y. 1973. Palynologie du Mesozoique Saharien: Traitement des donnees par rinformatique et applications a la stratigraphie et al., a sedimentologie. Mem. Mus. His. Nat., Paris, Serie C. 27: 3- 284.

Rushforth. S.R. 1976. The Plant Kingdom Evolution and Form. Prentice-Hall, INC., Englewood Cliffs, New Jersey. U.S.A.

Saad, S.I., 1975. Palynological studies in Nubia Sandstone from kharga Oasis, Egypt. Pollen et Spores xv III: ( 3).

Saad, S.I. \& Ghazaly, G., 1976. Palynological studies in Nubia Sandstone from kharga Oasis. Pollen et Spores 18 (3): 407-470.

Saad, S.I. 1978, Palynological studies in the Egyptian Western Desert: Umbarka 1X Borehole. Pollen et Spores 20 (2): 361-301.

Schrank, E. 1987. Paleozoic and Mesozoic palynomorphs from northeast Africa (Egypt and Sudan) with special reference to Late Cretaceous pollen and dinoflagellates. Berliner geowiss. Abh. (A) 15 (1): 249-310.

Sukh Dev, 1961. The fossil flora of the Jabalpur series. 3. Spores and Pollen grains. Palaeobotanist 8 (1-2): 43-56, Ranchi.

Thomson, P.W. \& Pflug, H.D. 1953, Pollen und Sporen des mitteleuropaischen Tertiars. Palaeontographica B, 94: 1-138.

Wilson, L.R. \& Webster, R.M. 1946. Plant microfossils from a Fort Union Coal of Montana . Am .J. Bot . 33 : 271-278. 
$-13-$ 
$-15-$ 
